\title{
21. TRIASSIC-LOWER CRETACEOUS WIRELINE LOG DATA FROM SITES 759 THROUGH $764^{1}$
}

\author{
Ron Boyd ${ }^{2}$ and Alistair Bent ${ }^{3}$
}

\begin{abstract}
Wireline log data from ODP Sites 759 through 764 are among the first to be published from the Exmouth-Wombat plateau region. $\log$ analysis at these sites defined boundaries, trends, and $\log$ units. These analyses were also used to interpret the lithology at each site and, where possible, to correlate between adjacent sites on each plateau. The continuous data response of wireline logs proved useful for interpreting lithology and other sedimentary features in zones of poor recovery and for positioning partly recovered intervals at their correct depth. Continuous log response also enabled a more confident interpretation of depositional environments from trend analysis and assisted the interpretation of relative sea-level variation.

Results enabled detailed correlation between Sites 762 and 763 on the southern Exmouth Plateau and a broader relationship to be established between Sites 759 and 760 on the Wombat Plateau. Wireline log data from the Exmouth and Wombat plateaus document two tectonic depositional cycles on the northwest Australian margin. The first is Late Triassic in age and follows a Permian rifting event. It was encountered only on the Wombat Plateau. The second is Early Cretaceous, documents a continental breakup event, and can be identified on both the Wombat and Exmouth plateaus. Superimposed on the large tectonic events are cycles of shorter duration reflecting sea-level oscillations and fluctuations in sediment supply.
\end{abstract}

\section{INTRODUCTION}

\section{Location and Setting}

Wireline log data were collected at all six sites $(759,760$, $761,762,763$, and 764) drilled during Ocean Drilling Program (ODP) Leg 122 on two submarine plateaus adjacent to the northwest Australian continental margin (Fig. 1). Sites 762 and 763 are on the southern Exmouth Plateau (Exon and Willcox, 1980) whereas the other four site are located to the north on the adjacent Wombat Plateau (Exon et al., 1982; von Rad and Exon, 1983). Present water depth at these sites ranges from 1359 to $2698 \mathrm{~m}$.

In the early Mesozoic, the present northwest Australian margin was part of a continental rift zone on northeast Gondwanaland that bordered the Tethys sea to the north (von Rad and Exon, 1983; Fullerton et al., 1989). An initial phase of deep crustal extension and thinning of the Exmouth-Wombat Plateau area occurred during the Permian (Williamson and Falvey, 1988) and was followed by rifting during the TriassicJurassic (Audley-Charles, 1988). A thick paralic sequence of Triassic-Early Cretaceous (Fig. 2) clastic and carbonate rocks prograded northward from the Australian and possibly Greater Indian continents into the Tethys sea (Exon and Willcox, 1980). The Jurassic was a time of uplift, tilting, and erosion over much of the area. Seafloor spreading began on the margins of the Exmouth and Wombat plateaus during a second phase of rifting in the Late Jurassic to Early Cretaceous (Audley-Charles, 1988). During the middle Cretaceous, subsidence continued, the southern clastic supply ended, and sedimentation switched first to hemipelagic mudstones, then to marls, and finally, by the Late Cretaceous, to pelagic deposition of chalks and oozes (Boote and Kirk, 1989).

\footnotetext{
1 von Rad, U., Haq, B. U., et al., 1992. Proc. ODP, Sci. Results, 122 College Station, TX (Ocean Drilling Program).

2 Center for Marine Geology, Dalhousie University, Halifax, Nova Scotia, B3H 3J5, Canada.

3 British Petroleum, 301 St. Vincent Street, Glasgow, G2 5DD, Scotland.
}

\section{Objectives and Content}

Here we concentrate primarily on log data from the Triassic-Early Cretaceous period of southern-sourced clastic sediment supply. These log data are among the first to be published from the Exmouth-Wombat plateau region. Log analysis of the various log string data combinations (see "Methods") was used to define boundaries, trends, and log units (e.g., Fig. 3). These analyses have been used to interpret the lithology at each site and, where possible, to correlate between adjacent sites on each plateau. Together with seismic and biostratigraphic data, log analysis has also been used to interpret the depositional sedimentary environments and to infer relative sea-level history. Wireline logs provide a relatively continuous data response and have proved useful in the present study for interpreting lithology and other sedimentary features in zones of poor recovery and for positioning partly recovered intervals at their correct depth. Continuous log response enables a more confident interpretation of depositional environments from trend analysis and particularly assists interpretation of continuous sea-level variation.

The wireline log data are presented separately, first for the Wombat Plateau, and second for the Exmouth Plateau. Because the times of deposition logged on the two plateaus mostly do not coincide, correlation between sites was attempted only within each plateau.

\section{METHODS}

Geophysical well logging procedures for each site and a brief outline of the operation of each tool used on Leg 122 are given in Haq, von Rad, O'Connell, et al. (1990). A variety of well log data was collected on Leg 122. The tool combination run at each site generally depended on several factors, including hole conditions and time. Of principal interest to this study was the seismic-stratigraphic tool string consisting of the long-spacing sonic (LSS) tool or sonic digital tool (SDT), the dual induction (DIL) or phaser induction (DIT-E) tool, the gamma-ray (GR) or natural gamma spectrometry tool (NGT), and the caliper tool (MCD). Where hole conditions prevented running the seismic-stratigraphic tool string, data were ob- 


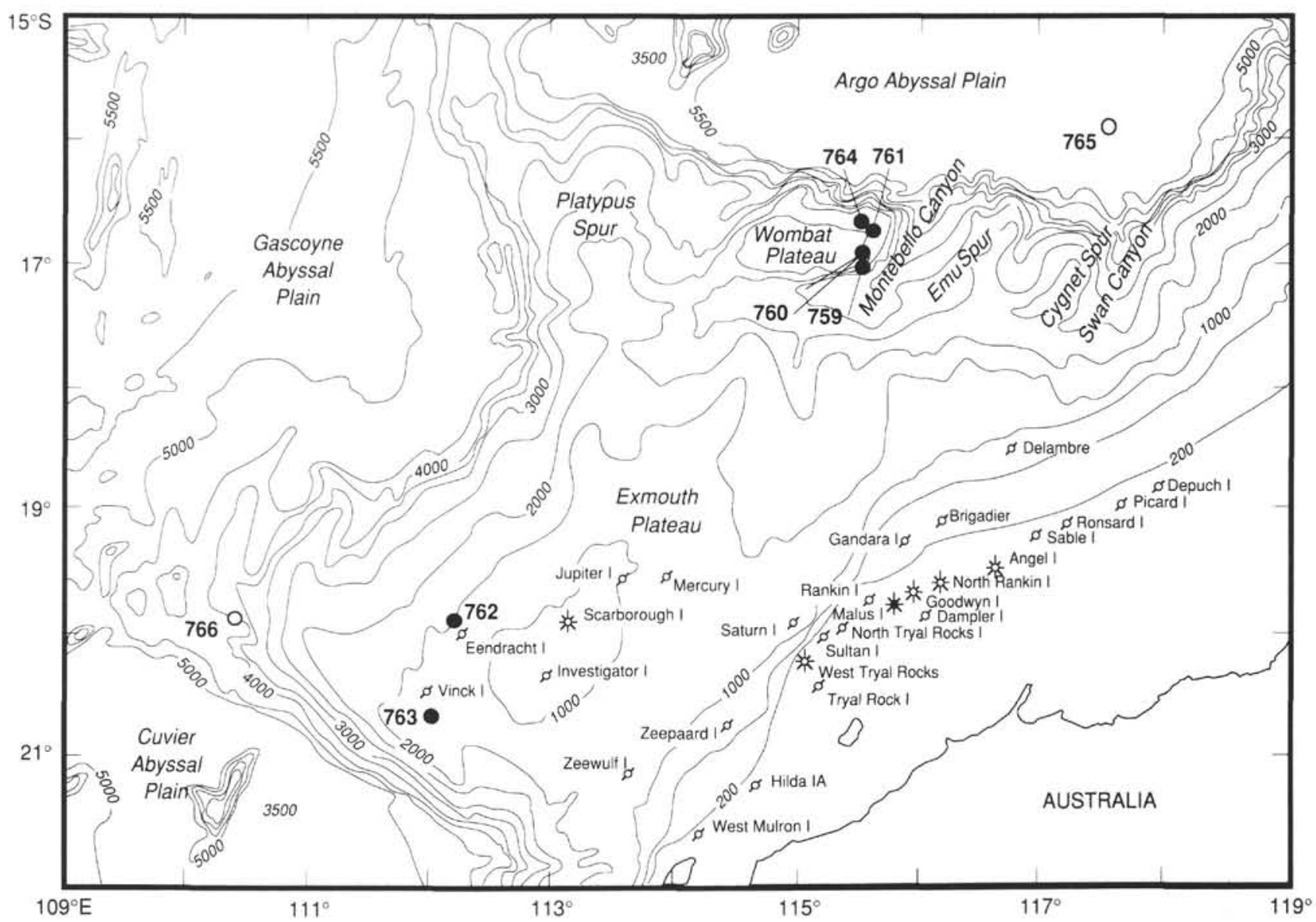

Figure 1. Bathymetric map of the Exmouth Plateau region showing the location of ODP sites (solid circles = Leg 122 , open circles $=$ Leg 123) and commercial wells. Bathymetry is in meters (N. F. Exon, unpubl. data). Log data from Mesozoic strata at all six Leg 122 sites are discussed in this paper.

tained from the lithoporosity combination and the geochemical combination, both of which can be run effectively in drill pipe. The lithoporosity combination includes the NGT, lithodensity (LDT), and compensated neutron (CNT-G) tools. The geochemical combination includes the NGT, induced gammaray spectrometry (GST), and the aluminum clay tools (ACT).

An analysis of the wireline log data was performed using techniques outlined in Rider (1986). This analysis consisted of first identifying lithology from the gamma, resistivity, and sonic logs and cross-correlating these log identifications with the recovered core intervals. All site depths are listed both in meters below sea level (mbsl) and in meters below seafloor (mbsf) to enable correlation among core, log, and seismic data. Sections of poor core recovery generally coincided with intervals interpreted as sandstone or massive limestone from the logs. A log facies analysis was then performed using baseline, trend line, log shape, and abrupt break techniques. From this analysis an interpretation of depositional environments and relative sea level was derived. Sequence stratigraphic procedures follow those described in Vail (1987), whereas sequence stratigraphic nomenclature for sequences, systems tracts, and sea level follows that of Van Wagoner et al. (1987).

\section{WOMBAT PLATEAU}

The four sites drilled on the Wombat Plateau (Fig. 1) were all terminated in Triassic sediments. The drill sites encountered a sequence of Triassic marginal marine and marine deposits overlain by Cretaceous and Cenozoic sediments. Jurassic sediments were absent over the plateau. The Wombat Plateau is interpreted as a northern segment of the Exmouth Plateau which formed during the Middle Jurassic rift phase (von Rad et al., 1989). The oldest sediments encountered on the plateau consist of early to middle Carnian to Norian marginal marine sediments, predominantly carbonates, overlain by fully marine Rhaetian crinoidal limestones, reefal complexes, and shelf limestones.

A major subangular unconformity dissects the Triassic over the area, and the absence of Jurassic sediments is attributed to tilting and uplift of the plateau prior to the onset of seafloor spreading in the Argo Abyssal Plain. Subsequent breakup of the margin at about Callovian?-Berriasian times saw rapid subsidence of the Wombat Plateau, and the Triassic unconformity was transgressed, depositing condensed sections of Cretaceous glauconitic limestones and belemnite-rich mudstones.

By middle Cretaceous times clastic supply to the area diminished and hemipelagic conditions were established over the Wombat Plateau, resulting in the middle to late Aptian deposition of deep-water claystones. These are succeeded by an organic black shale, marking the Cenomanian/Turonian boundary and overlain by pelagic carbonate facies.

\section{Log Character at Site 759}

The total and spectral gamma-ray log data are of excellent quality over the open-hole section, and the electric logs recorded good data over most of the open hole. The sonic log 


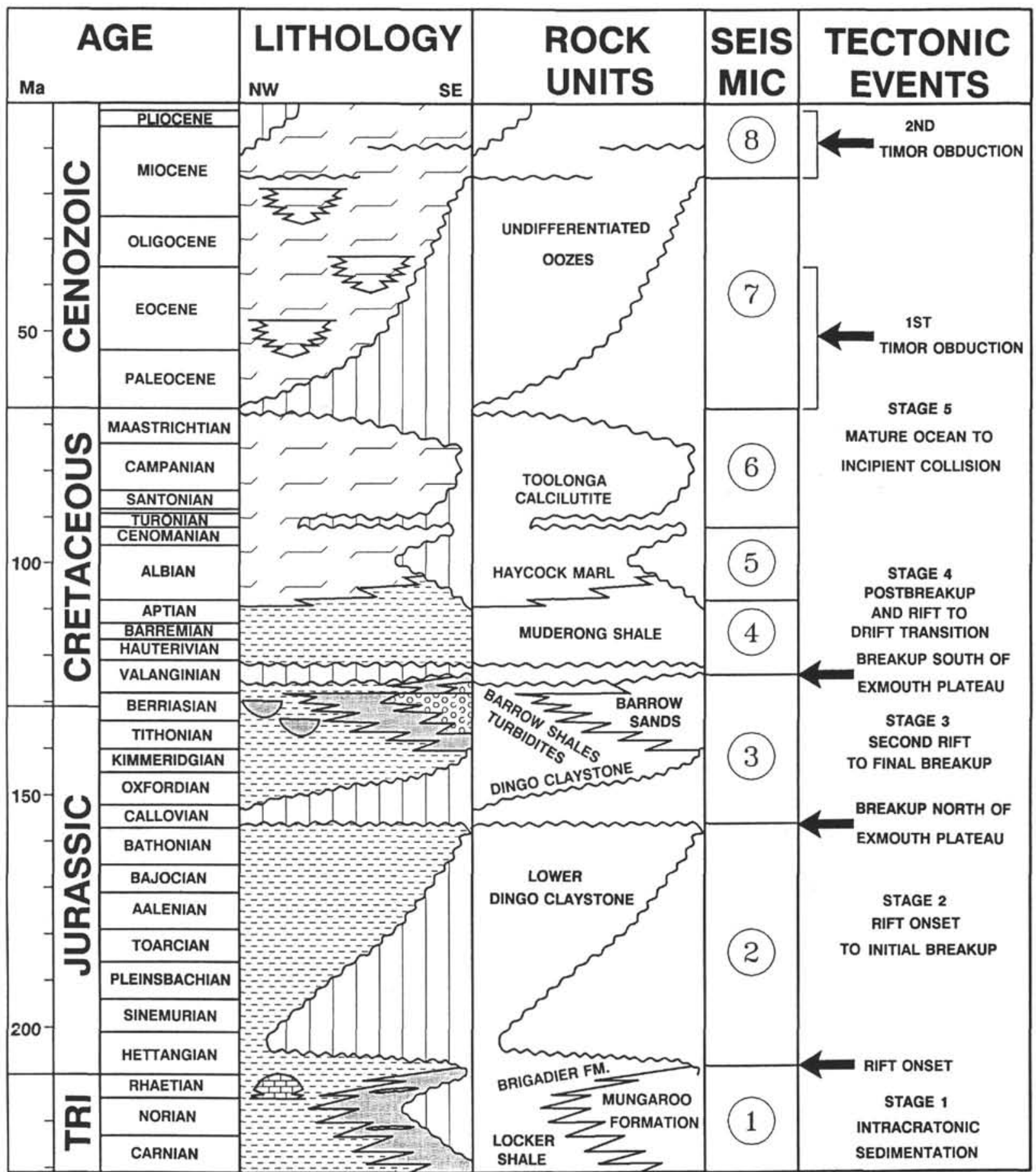

Figure 2. Stratigraphic summary of the Exmouth Plateau region from the Triassic to Holocene (from Boyd et al., this volume). Chronostratigraphy is from Haq et al. (1987). Lithology: dashes = mudstone, circles = sandstone, fine dots = conglomerate, bent bars $=$ marl and ooze, and brick = limestone and marl. Vertical lines indicate hiatuses. The correlated seismic packages are discussed in Boyd et al. (this volume).

provided reliable data up to $2303 \mathrm{mbsl}$ ( $210.4 \mathrm{mbsf})$. Intervals of bad data are shown as gaps on Figure 3.

The log character from the bottom of the hole to $2302 \mathrm{mbsl}$ is relatively monotonous (Fig. 3). Above this depth significant variations in the log responses occur but are within an overall upward-decreasing trend on the gamma-ray log response to the base of the pipe at $2158 \mathrm{mbsl}$ ( $66.4 \mathrm{mbsf})$. An unusual log response at $2232 \mathrm{mbsl}$ ( $140.4 \mathrm{mbsf}$ ) characterized by an increase in the gamma-ray, resistivity, and velocity log responses (Fig. 3) suggests the presence of a heavily cemented unit with a significant radioactive component. Overall, 23 units were identified using $\log$ trends from the bottom of the hole at $2400 \mathrm{mbsl}$ ( 308 $\mathrm{mbsf})$ to the base of the drill pipe at $2158 \mathrm{mbsl}(66.4 \mathrm{mbsf})$.

\section{Log Character at Site $\mathbf{7 6 0}$}

Two wireline suites were run at Site 760 and the gammaray, electric logs, and neutron porosity data are all of good quality. Data from the long-spaced sonic tool are not reliable. 


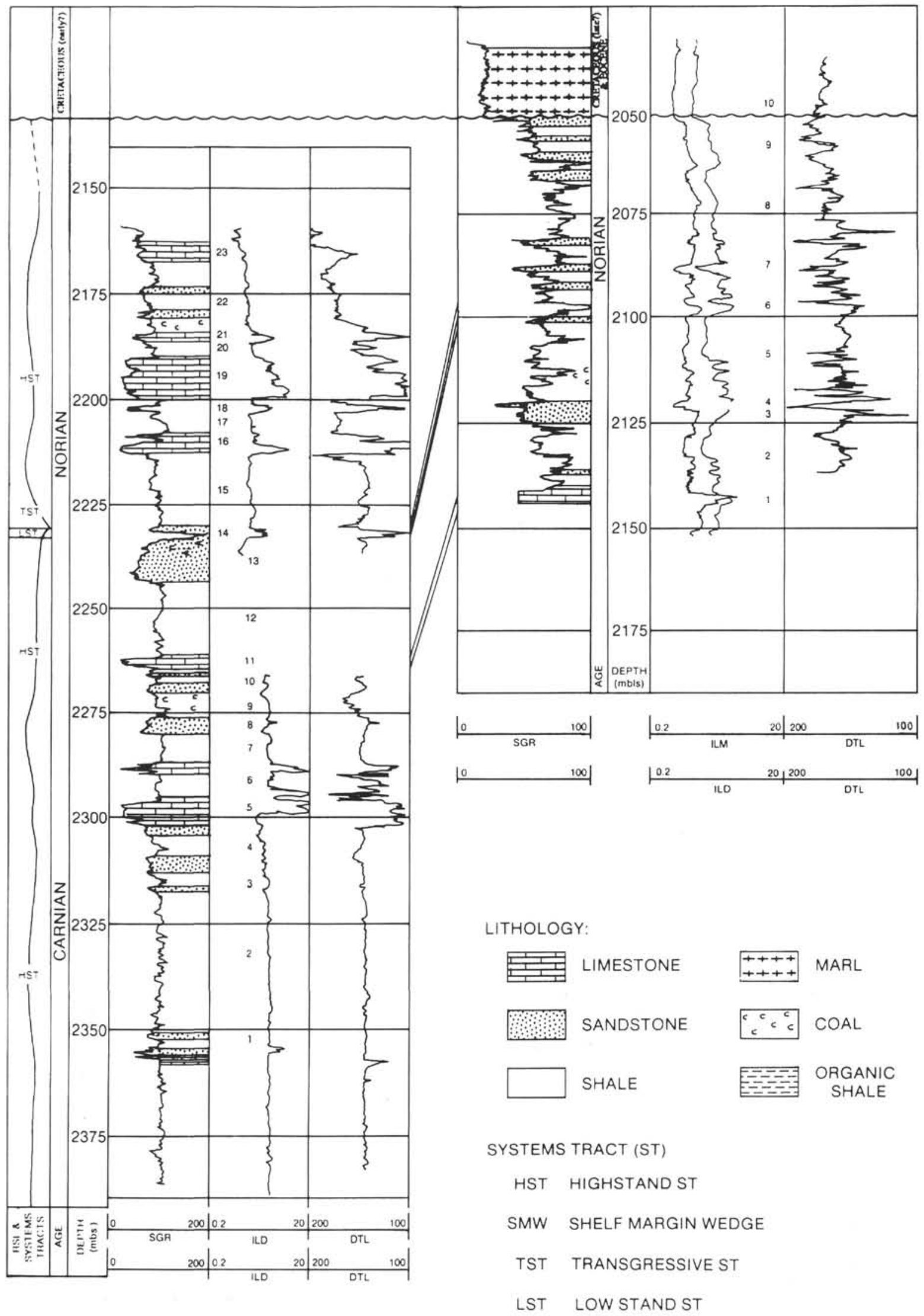

Figure 3. Wireline log data from Sites 759 (left) and 760 (right) for the gamma-ray (SGR), resistivity (ILD to the left and ILM to the right), and sonic (DTL) logs. Also shown are the interpreted lithology, log units, relative sea level, and correlation between the two sites. 
No overall broad trends are discernable from the bottom of the hole up to $2049.7 \mathrm{mbsl}$ ( $80 \mathrm{mbsf}$ ), where there is a sharp drop in the gamma-ray log and resistivity log response (Fig. 4). Between the base of the pipe at 2032.7 mbsl ( $63 \mathrm{mbs})$ and $2049.7 \mathrm{mbsl}$ ( $80 \mathrm{mbsf})$, there is a downward decrease in the sonic velocity and a corresponding increase in the neutron porosity $\log$ response. Two intervals with unusual log responses occur over the logged interval. The first, at 2119.7 mbsl ( $150 \mathrm{mbsf}$ ), is $1.5 \mathrm{~m}$ thick and is characterized by a low gamma-ray log response ( 30 API units) and a pronounced increase in the interval transit time to $220 \mu \mathrm{s} / \mathrm{ft}$, concurrent with a slight decrease in the resistivity log response (Fig. 4). The unit is also marked by an increase in the neutron porosity reading to $70 \%$ and a decrease in the thorium to potassium ratio. At $2096.7 \mathrm{mbsl}$ (127 mbsf) is a second 1.5-m-thick unit that has a high gamma-ray log response (140 API units) that corresponds with an increase in the thorium content to $22 \mathrm{ppm}$ and a slight increase in the uranium content (Fig. 4). The neutron porosity log indicates a reading of $40 \%$, and both the velocity and resistivity response increase slightly. It was possible to log only a relatively short section of the total open hole at Site 760 as a result of poor hole conditions, and the log trend analysis of this section identifies 10 units.

\section{Log Character at Site 761}

Bridging problems in Hole $761 \mathrm{C}$ made it impossible to run open-hole logs over much of the section, and the DIT-E, SDT, and NGT combination was run only over a short section of hole between 2428 and $2293 \mathrm{mbsl}$ (260.1 and $125.1 \mathrm{mbsf}$ ). Data from the remaining section of hole down to $2583 \mathrm{mbsl}$ (415.1 mbsf) were obtained by running the geochemical tool through pipe. Data from the geochemical tool are of good quality, but between 2513 and $2458 \mathrm{mbsl}$ ( 345.1 and $290.1 \mathrm{mbsf}$ ) the gamma-ray data are invalidated by irradiation of the pipe.

The open-hole log data are generally characterized by a low gamma-ray log response (10-15 API units) and by low velocity and electric log responses (Fig. 5). A broad peak in the gamma-ray log response at $2338 \mathrm{mbsl}$ (170.1 mbsf) indicates the position of the Cretaceous/Tertiary boundary interval. A small increase in the gamma-ray log and electric log response at $2408 \mathrm{mbsl}$ ( $240.1 \mathrm{mbsf})$ suggests the presence of a clay unit with lower porosity than the overlying sediments.

Log responses from the geochemical tool below the openhole section define a long interval of calcium abundance. Small troughs in the calcium log and corresponding peaks in the silica and aluminium responses indicate the presence of clastic-rich stringers (Fig. 6). These stringers are more predominant below 2508 mbsl (340.1 mbsf).

\section{Log Character at Site $\mathbf{7 6 4}$}

Technical problems at Site 764 prevented running openhole logs. However, it was possible to run both the geochemical tool and the neutron porosity log tool through the drill pipe with relatively good results. Results from the total gamma-ray $\log$, run with the neutron porosity tool, can be used only for the identification of general trends, because of the irradiation of the drill pipe and consequent high gammaray counts over the logged section.

From the base of the logged section at $2983.6 \mathrm{mbsl}(285$ mbsf) up to $2910 \mathrm{mbsl}$ ( $211.4 \mathrm{mbsf})$ there is a general upward increase in the gamma-ray log response concomitant with an increase in the neutron porosity reading (Fig. 7). Gamma-ray peaks over this interval coincide with silicon-, thorium-, and potassium-enriched intervals (Fig. 8). Between 2910 and 2820.6 mbsl (211.4 and $122 \mathrm{mbsf}$ ) low gamma-ray, thorium, and potassium log responses coincide with high silicon and low aluminium ratios. The neutron porosity log displays a broad upward increase to near the top of the unit and then a sharp decrease at $2820.6 \mathrm{mbsl}$ (122 mbsf).

Above $2820.6 \mathrm{mbsl}$ (122 mbsf) there is a shift in the gamma-ray log response which gradually increases to a maximum at $2756.6 \mathrm{mbsl}$ ( $58 \mathrm{mbsf}$ ) with a corresponding peak on the neutron porosity log response. Intervals of low gamma-ray response (10 API) and porosity over this unit correspond with high calcium readings from the geochemical log response. Above this unit the gamma-ray log response falls to below 10 API units and then displays a very slight upward increase to the seafloor at $2698.6 \mathrm{mbsl}$. The upward increase in porosity to the seafloor reflects the increasingly unlithified nature of the sediment.

\section{Lithologic Interpretation}

Open-hole log responses at Sites 759 and 760 (Figs. 3 and 4) over the Carnian and Norian sections are indicative of a relatively mudstone-/siltstone-rich sequence with interbeds of sandstone and limestone. At Site 759 the limestone beds become thicker and more common toward the top of the Norian section. The shale and siltstone lithology at Sites 759 and 760 is characterized by high gamma-ray and neutron porosity log responses and low compressional-wave velocities. At Site 759 gamma-ray peaks at $2308 \mathrm{mbsl}$ (216.4 mbsf) and $2274 \mathrm{mbsl}$ (182.4 mbsf) are indicative of more organic-rich intervals and correspond with an increase in uranium/thorium and potassium on the geochemical log.

Sand and sandstone units are typified by relatively higher gamma-ray $\log$ responses of between 40 and 60 API units, a reflection of the high clay content and fine nature of these sandstones. Both the sonic $\log$ and neutron $\log$ indicate porosities of between $70 \%$ and $75 \%$ in the sand and sandstone units, but it is suggested that the actual porosities are probably more in the region of $35 \%$ to $40 \%$. The discrepancy is probably due to the high clay content and generally unlithified nature of the sands. For example, unit 4 at $2119.7 \mathrm{mbsl}(150 \mathrm{mbsf})$ at Site 760 is characterized (Fig. 4) by a sharp decrease in the velocity and resistivity $\log$ response concomitant with a reduction in the gamma-ray log response; this is a common feature of uncompacted sands. Cemented sandstone units at $2232 \mathrm{mbsl}$ (140.4 mbsf) and $2096 \mathrm{mbsl}$ (126.3 mbsf) at Sites 759 and 760 , respectively, display an unusually high gamma-ray $\log$ response that can be attributed to the presence of thoriumbearing heavy minerals.

Limestone intervals at Site 759 are characterized by low gamma-ray log responses and relatively high resistivities and compressional-wave velocities (Fig. 3). Both of these properties are a result of the low porosity and high degree of cementation of the limestones seen in the core. Limestone lithology at Site 759 also displays a distinctive "blocky" character on the gamma-ray log compared with the upwardfining and -coarsening trends over the sandstone interval. Only one limestone unit was identified at Site 760 , at the base of the logged section, where it is characterized by a sharp decrease in the neutron porosity log and an increase in the resistivity $\log$ response. As the neutron $\log$ porosity to real porosity has a $1 / 1$ relationship over limestone, the lithology in which it is calibrated, the value of $10 \%$ can be taken as real.

The sediments above the top Triassic unconformity at $2049.7 \mathrm{mbsl}$ ( $80 \mathrm{mbsf}$ ) at Site 760 are interpreted as chalks or marls passing up into oozes with characteristic low gammaray $\log$ responses and neutron log porosities ranging from $50 \%$ to $55 \%$. A $40-\mathrm{cm}$-thick manganese crust at the Triassic unconformity was recovered in the core but was beyond the resolution of the logs. Chalk and oozes were also identified above the top Triassic unconformity at $2423.4 \mathrm{mbsl}(255.5$ mbsf) and $2747.9 \mathrm{mbsl}(49.3 \mathrm{mbsf})$ at Sites 761 and 764, 

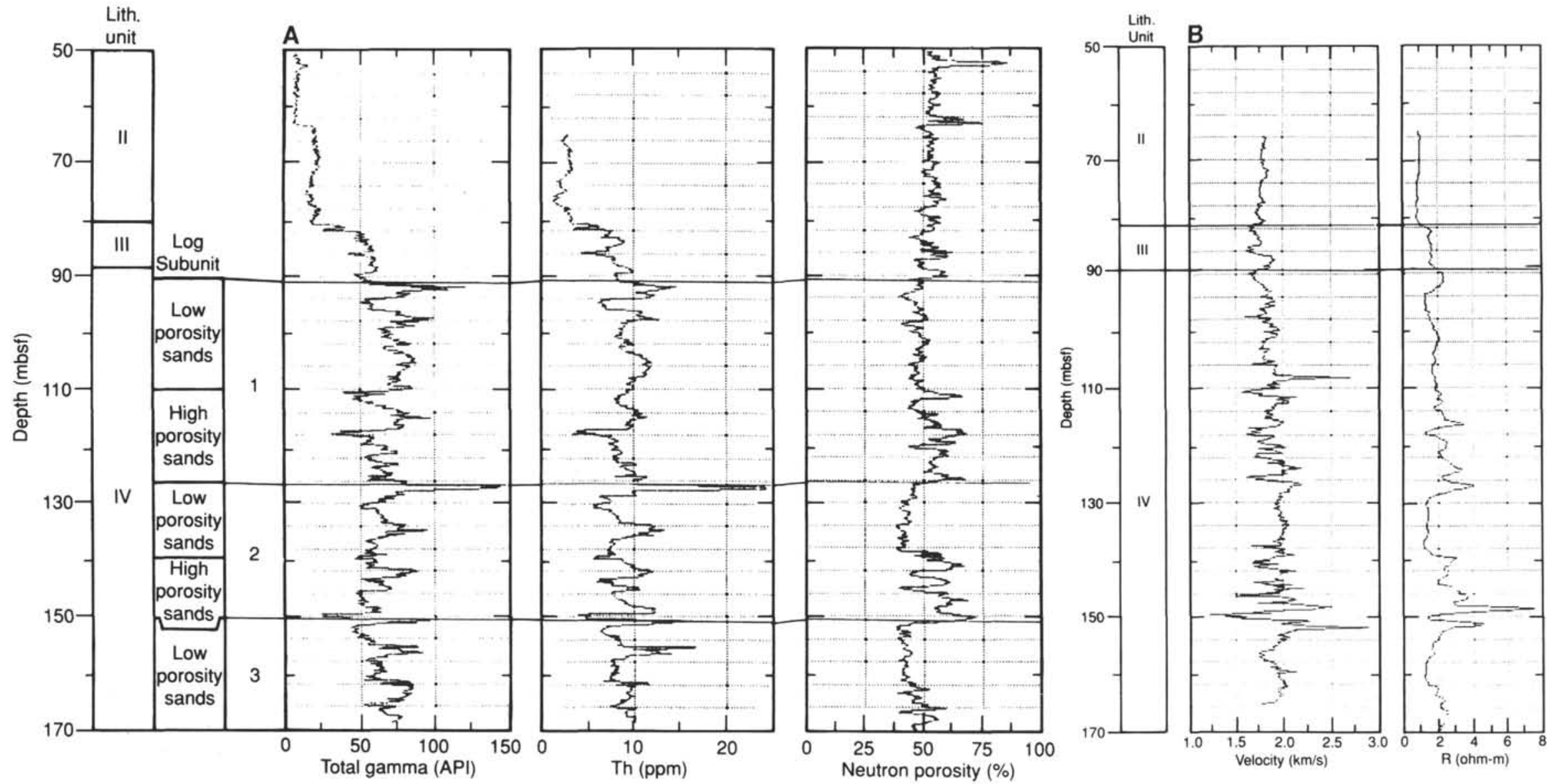

Figure 4. Wireline log data from Site 760. A. Open-hole logs of total gamma-ray, thorium count (Th), and neutron porosity. B. Velocity and deep formation resistivity (R) logs. Also shown is the correlation of the logs to lithologic units defined in Haq, von Rad, O'Connell, et al. (1990). 


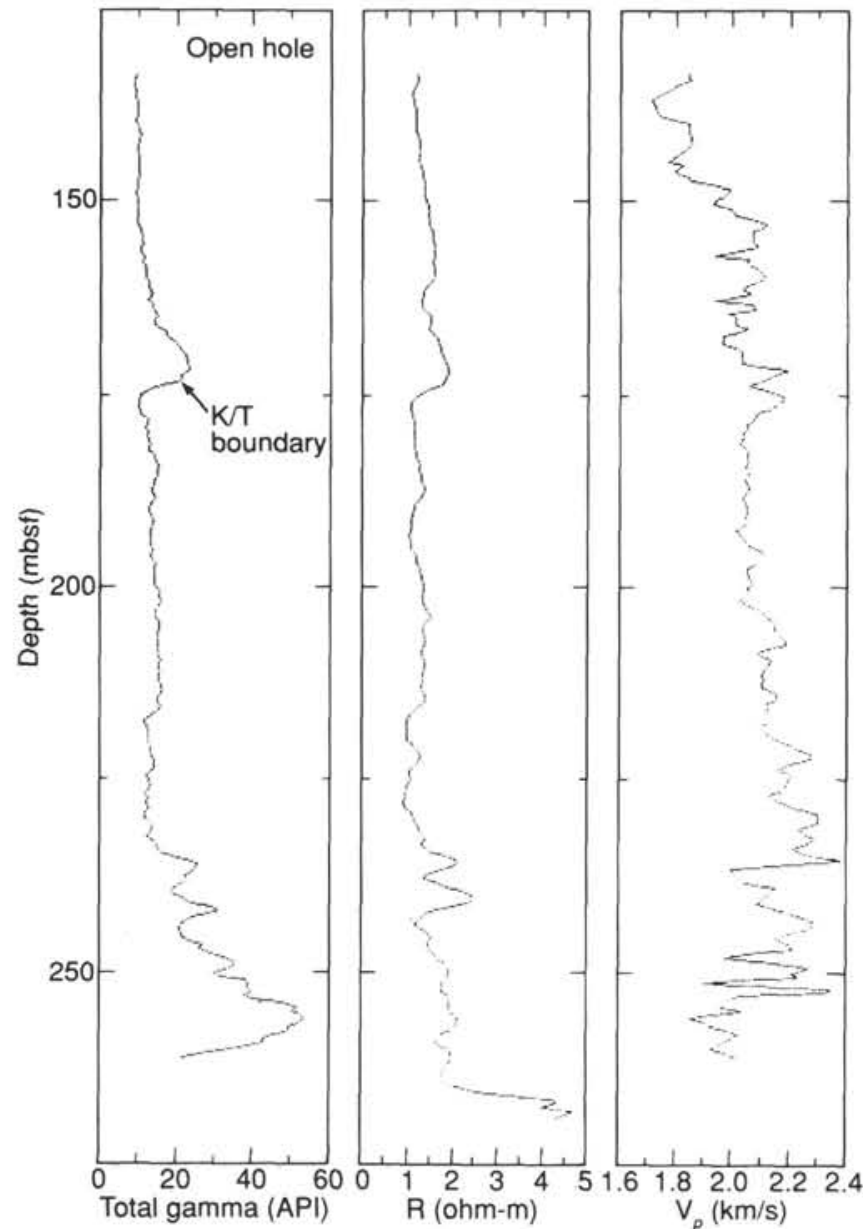

Figure 5. Open-hole logs of total gamma-ray, resistivity (R), and compressional-wave velocity $(\mathrm{V} p)$ recorded at Site 761 by the seismicstratigraphic tool string. The data were smoothed using a $1.0-\mathrm{m}$ running average calculated at $0.5-\mathrm{m}$ intervals.

respectively. The equivalent section was not logged at Site 759. Lithology below the top Triassic unconformity at Sites 761 and 764 (Figs. 5-8) consists of Rhaetian carbonates and carbonate mudstones, and their overall log character differs significantly from that of the Triassic sequences at Site 759 and 760 .

At Site 761 pure limestones predominate down to 2490 mbsl (322.1 mbsf), below which the limestones become increasingly impure, grading into carbonate mudstone and marls as the silica content (in the gamma-ray spectrometry capture log) increases (Fig. 6). Toward the base of the hole, the gamma spectroscopy ratio log clearly distinguishes limestone from mudstone using the silicon/calcium ratio. The only sandstone interpreted on the logs at Site 761 occurs between 2430 and 2426 mbsl (262.1 and $258.1 \mathrm{mbsf}$ ).

Log analysis below the top Triassic unconformity at Site 764 shows that, as for Site 761, carbonate lithology is predominant. Core recovery over much of this section was very poor and it is therefore difficult to ground-truth $\log$ analyses. However, variations in the different geochemical log responses allow for the definition of broad trends over the logged section. Iron-rich limestones and carbonate mudstones are identified in the interval between 2983.6 and $2910 \mathrm{mbsl}$ (285 and $211.4 \mathrm{mbsf}$ ) at Site 764. Above this, the very low gamma-ray, thorium, and potassium log responses over the section up to $2820.6 \mathrm{mbsl}$ (122 mbsf) are interpreted as limestone with very low detrital clay contents (Fig. 7). The increase in the gamma-ray log response above $2820.6 \mathrm{mbsl}$ (122 mbsf) indicates the presence of clay-rich carbonates with thin, purer limestone stringers. A marked increase in the neutron porosity log response (Fig. 8) just below the top Triassic unconformity at $2753.6 \mathrm{mbsl}$ ( 55 mbsf) coincides with an increase in the calcium log response and may represent a more porous grainstone.

\section{Correlation of Sites 759, 760, 761, and 764}

Because of the variety of logging techniques that had to be adopted at the Leg 122 sites on the Wombat Plateau, log correlation among the sites is only possible over limited intervals. Figure 3 shows logs from Sites 759 and 760 , tied at the top Triassic unconformity. Tentative correlations across the underlying Norian section are depicted, notably the occurrence of a radioactive sandstone in unit 14 at Site 759 and unit 6 at Site 760 . These units may relate to a single event with important implications for relative sea-level interpretation, as discussed in the following section.

\section{Interpretation of Depositional Environments and Relative Sea Levels on the Wombat Plateau}

At Sites 759 and 760 the log units and overall log characteristics below the top Triassic unconformity are indicative of restricted conditions with limited clastic input interrupted by periods of shallow-marine limestone deposition.

The basal section at Site 759, from 2400 to about $2305 \mathrm{mbsl}$ (308.4 to $213.4 \mathrm{mbsf}$ ), consists of an upward-shoaling clastic sequence that was probably deposited in a prodelta or basinal environment. Above 2305 mbsl (213.4 mbsf) the alternating limestone, mudstone, and upward-fining sandstone lithology is considered to represent deposition on a shallow platform with the environment fluctuating from a marginal marine/ lagoon type to intertidal and shallow-marine types. Individual facies include lagoonal mudstones, tidal channel sandstones, and shallow-marine carbonates. The cemented sandstone unit identified at both Sites 759 and 760 is interpreted as a placer deposit. Carbonate facies are less prevalent at Site 760 , but the overall depositional environment over the logged section is still essentially a restricted low-energy shoreline or lagoonal-type system. This is supported by rootlets in the cored mudstone intervals and a distinctive lack of marine fauna. Above the Triassic unconformity at Sites 759 and 760 deposition occurred in a deep-marine carbonate environment.

Relative sea level of the Carnian and Norian sections at Sites 759 and 760 appears to occur primarily within the highstand systems tract. At Site 759 a broad upward shoaling within the highstand systems tract marks the transition from a prodelta to marginal marine environment. At both Sites 759 and 760, smaller-scale upward-shoaling cycles result in a upward facies transition from lagoonal to tidal flat sediments capped by swamp or marsh deposits.

The occurrence of a placer deposit at Sites 759 and 760 is interpreted as the product of a low relative sea-level sand. The thin, unconsolidated sand overlying this unit at both sites is therefore interpreted as occurring within the subsequent transgressive systems tract.

In contrast to Sites 759 and 760 , sediments below the top Triassic unconformity at Sites 761 and 764 consist predominantly of Rhaetian marine carbonates. At Site 761 the log character at the base of the hole is interpreted as thinly interbedded limestone and mudstone units. The absence of sandstones over this interval, the clean nature of the interbedded carbonates, and the rapid alternation between carbonate and clastic deposition suggests transgressive/regressive conditions in a continental shelf environment. 

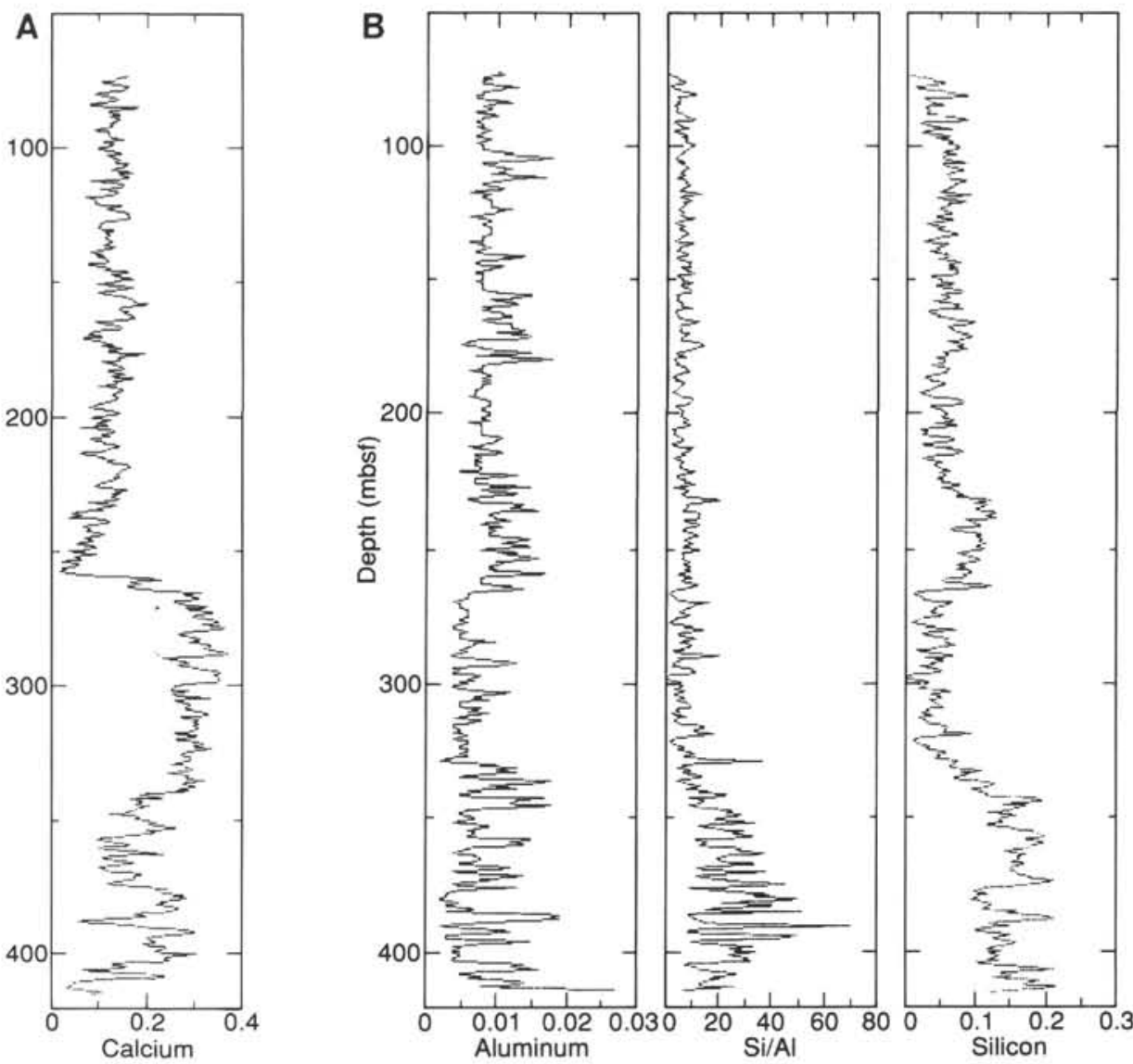

Figure 6. Profiles of relative elemental abundance at Site 761. A. The calcium abundance log indicates the presence of a limestone unit from 260 to 340 mbsf. B. Aluminum, silicon, and the ratio of silicon to aluminium $(\mathrm{Si} / \mathrm{Al})$.

Above $2553 \mathrm{mbsl}(385.1 \mathrm{mbsf})$ at Site 761 there is an upward transition into marls and calcareous mudstones. These sediments have a clastic component but are not as radioactive as the underlying mudstones and have lower carbonate contents. This interval suggests either a diminution of the clastic sediment supply by removal of the source, subsidence and deepening of the basin, or both. A higher energy carbonate lithology predominates from $2490 \mathrm{mbsl}$ (322.1 mbsf) to the top Triassic unconformity. Overlying the unconformity, a thin unconsolidated sandstone is interpreted as a transgressive coastal/continental shelf sand deposited under relatively high-energy conditions. Overlying the sandstone there is a gradual upward transition into bathyal chalks and oozes.

At Site 764 a marine carbonate environment predominates from the base of the logged section at $2983.6 \mathrm{mbsl}$ ( $285 \mathrm{mbsf}$ ) to the top Triassic unconformity. The core lithology indicates that the majority of this section is a coral and sponge reef complex with related perireefal facies. A sequence boundary can be tentatively drawn at the top of the reefal complex at $2771 \mathrm{mbsl}$ ( $72.4 \mathrm{mbsf}$ ), which is overlain by shallow-marine limestones and calcareous mudstones.

Relative sea-level interpretation of the Triassic sequence at Site 761 suggests that the section below 2553 mbsl (385.1 mbsf) is within a transgressive systems tract with a lower sequence boundary at about $2593 \mathrm{mbsl}$ (425.1 mbsf). This lower sequence boundary is extrapolated from the presence of nonmarine sediments in Core $122-761 \mathrm{C}-33 \mathrm{R}$, below the base of the log data. Above $2552 \mathrm{mbsl}$ (384.1 mbsf) the Triassic sediments are within the highstand systems tract. Similarly, at Site 764 the Triassic reef complex represents the highstand systems tract, the base of which lies below the logged interval at approximately $2979 \mathrm{mbsl}(280.4 \mathrm{mbsf})$. The sequence boundary at the top of the reefal complex at $2771 \mathrm{mbsl}(72.4$ mbsf) may represent a sharp drop in relative sea level, in which case the overlying marine carbonates represent the transgressive systems tract.

\section{EXMOUTH PLATEAU}

Drilling at both sites on the southern Exmouth Plateau terminated in Lower Cretaceous sediments (see Brenner et al., this volume). This period was characterized by high rates of northward clastic sediment supply (Exon and Willcox, 1980) lithologically and time equivalent to the Barrow Group (Fig. 2) on the adjacent Northwest Shelf (e.g., Barber, 1982). Between the Tithonian and Valanginian, a thick clastic wedge (Boot and Kirk, 1989) prograded from the southern transform margin northwestward onto subsiding continental crust (Erskine and Vail, 1988). This clastic slope/margin system deposited more than $1500 \mathrm{~m}$ of clastic sediments in less than 15 m.y., over a $300-\mathrm{km}$-wide depositional wedge and a number of relative sea-level cycles (Boyd et al., this volume; Haq et al., this volume). This clastic supply diminished after breakup south of the Exmouth Plateau (Fig. 2) and the initiation of seafloor spreading in the Hauterivian (Fullerton et al., 1989). A regional transgression spread east onto the Australian craton after the Neocomian and sedimentation on the subsiding Exmouth Plateau switched to deeper water facies and a 


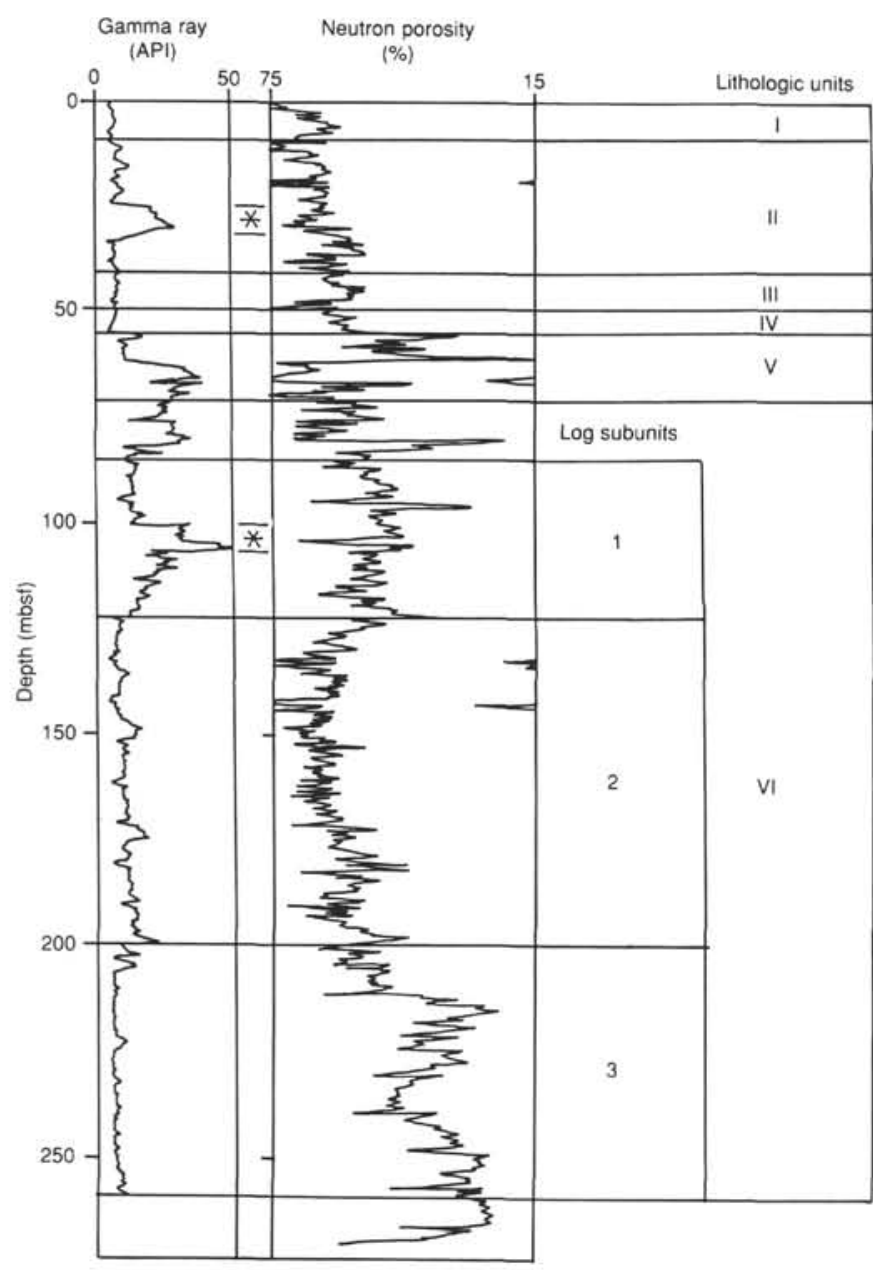

Figure 7. Gamma-ray and neutron porosity logs from Hole 764B. The neutron porosity values are affected by water displacing the bottomhole assembly and 8.25 -in. pipe above $201 \mathrm{mbsf}$, but the downhole porosity trends are considered valid. The log peaks at $24.0-30.5$ and 100-106 mbsf (asterisks) are due to pipe movement and are invalid. Also shown is the correlation of the logs to lithologic units defined in Haq, von Rad, O'Connell, et al. (1990).

carbonate-dominated composition (Exon and Willcox, 1980; Barber, 1982).

Our analysis of wireline log data from the southern Exmouth Plateau covers sediments deposited between the Berriasian and the Cenomanian. Site 763 was designed to sample a more proximal section of Barrow Group equivalent sediments whereas Site 762 was designed to sample a more distal section. Berriasian-Cenomanian sediments were logged between 2271 and $2170 \mathrm{mbsl}$ ( 911 and $810 \mathrm{mbsf}$ ) at Site 762 and between 2045 and 1750 mbsl (677.5 and $382.5 \mathrm{mbsf}$ ) at Site 763. At Site 763 only part of the seismic-stratigraphic string was run and data consist of gamma-ray, resistivity, and caliper logs. At Site 762 a full $\log$ suite from the seismic-stratigraphic string (sonic, caliper, resistivity, total gamma-ray, and thorium, potassium, and uranium spectral logs), geochemical string (total gamma-ray; thorium, potassium, and uranium spectral logs; and elemental yields of silicon, calcium, sulfur, aluminium, iron, hydrogen, and chlorine) and lithodensity string (neutron porosity, density, and gamma-ray) is available. Lithologic interpretations of the log data were ground-truthed with reference to equivalent core locations, where available, and correlated with adjacent proprietary lithologic and wire-

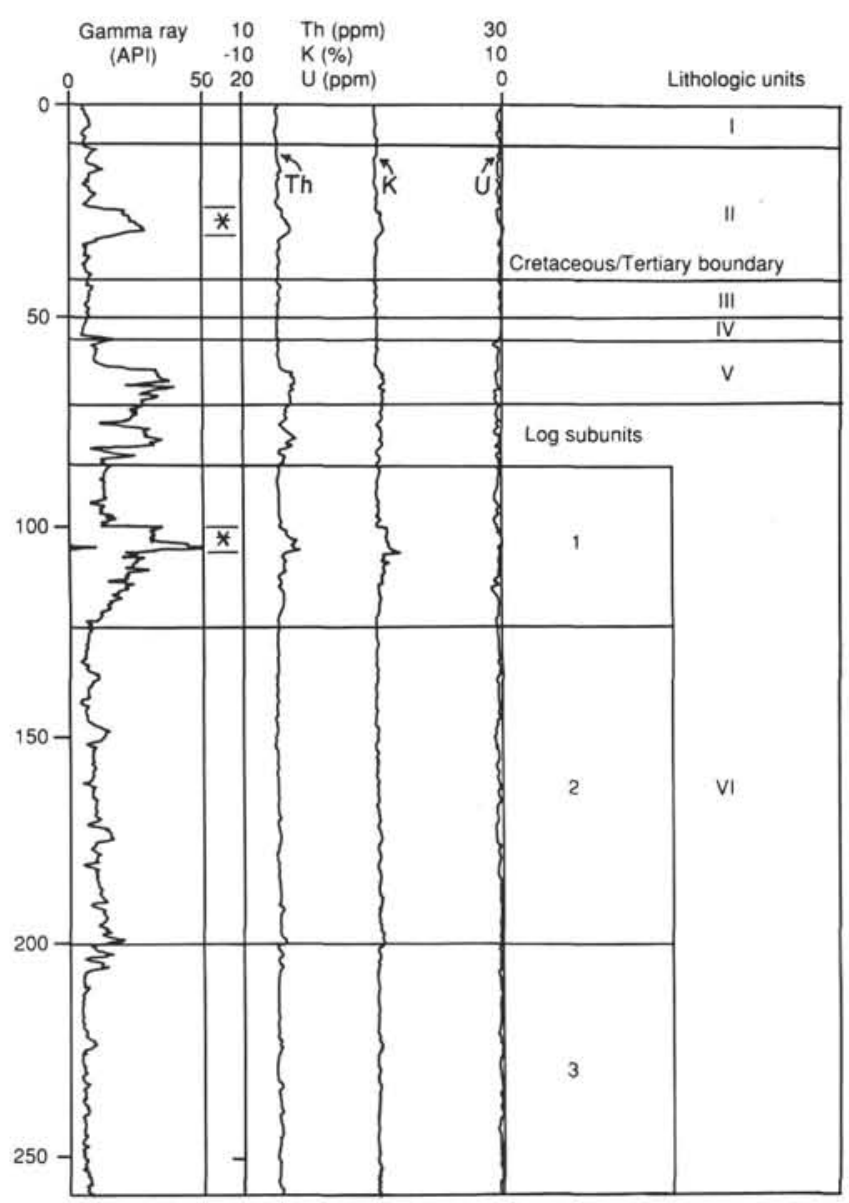

Figure 8. Gamma-ray, thorium, potassium, and uranium logs recorded in the pipe at Site 764. The log peaks at 24.0-30.5 and 100-106 mbsf (asterisks) are due to pipe movement and are invalid. Also shown is the correlation of the logs to lithologic units defined in Haq, von Rad, O'Connell, et al. (1990).

line log data (Esso Australia unpublished well completion reports, Vinck-1 and Eendracht-1). Environmental and sealevel interpretations were correlated with regional seismic data (Boyd et al., this volume) and age determinations are from Brenner et al. (this volume).

\section{Log Character at Site 763}

The data quality of the gamma-ray $\log$ is high throughout Site 763 whereas the electric logs display a subdued but interpretable trace (Fig. 9). The combination of the two logs and reference to the adjacent industry Vinck-1 well enabled subdivision and interpretation of the wireline log data. The most prominent features on the electric logs were a series of resistivity peaks most clearly seen between 1991 and $2002 \mathrm{mbsl}$ (623.5 and $634.5 \mathrm{mbsf}$ ), 2014 and 2017 mbsl (646.5 and $649.5 \mathrm{mbsf}$ ), and 2226 and $2228 \mathrm{mbsl}$ (858.5 and $860.5 \mathrm{mbsf}$ ) (Fig. 9). Where not obscured by other trends, the resistivity peaks were observed to correlate with decreased gamma-ray response. The interval between 2044 and 2008 mbsl (676.5 and $640.5 \mathrm{mbsf}$ ) contains two thicker units of low resistivity and gamma-ray response. Three intervals of higher gamma-ray response centered at 1946, 1966, and $1986 \mathrm{mbsl}$ (578.5, 598.5, and $618.5 \mathrm{mbsf}$ ) are more intense than other gamma-ray peaks and, as shown on the spectral gamma-ray log (Fig. 10), are primarily derived from a uranium source. A prominent trend of decreasing gamma-ray response was observed between 1946 and $1923 \mathrm{mbsl}$ ( 578.5 and $555.5 \mathrm{mbsf}$ ). With some minor variability, this feature of 


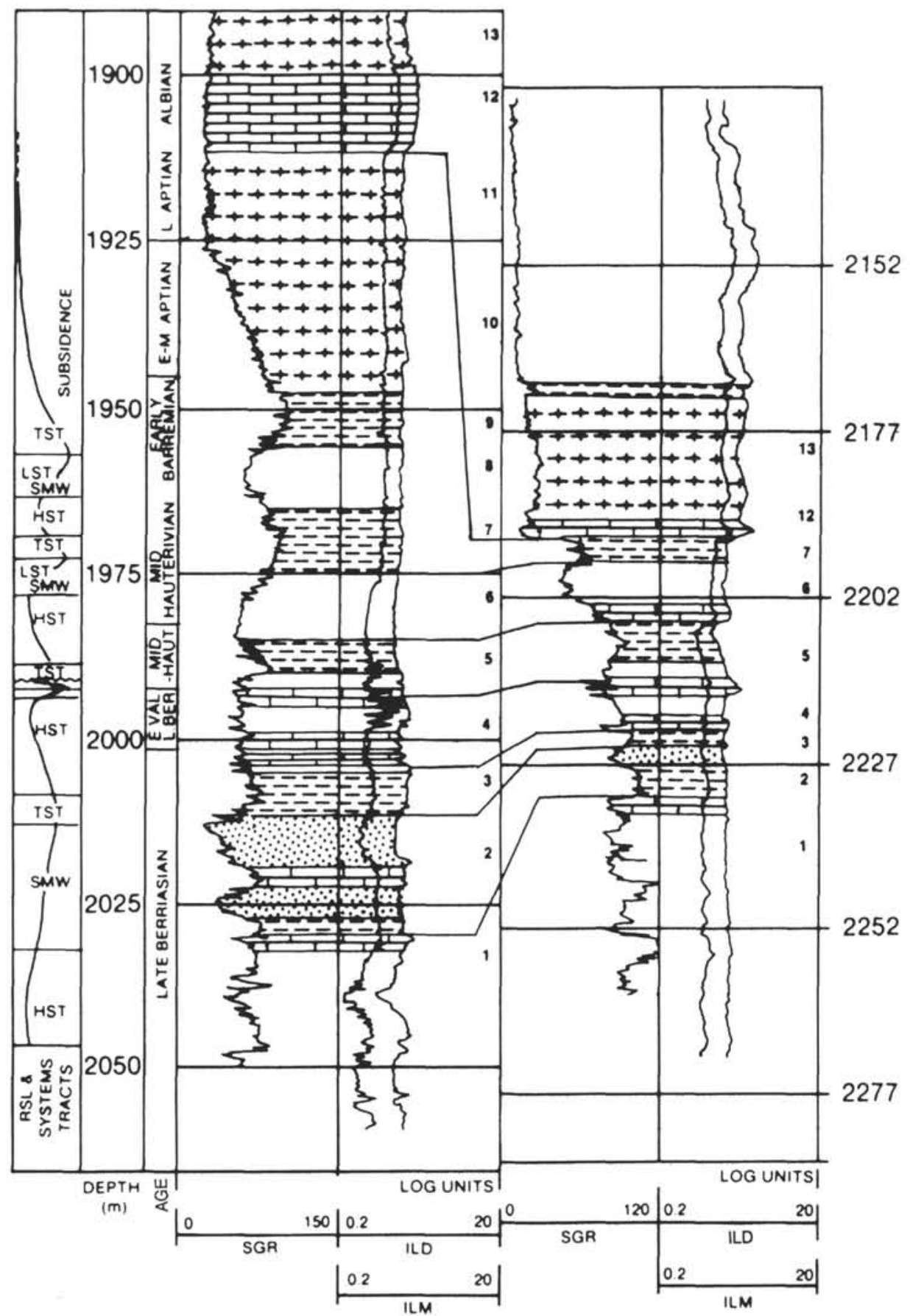

LITHOLOGY

\begin{tabular}{|c|c|c|c|}
\hline 至 & LIMESTONE & ++++ & MARL \\
\hline & SANDSTONE & $\begin{array}{lll}c_{0} & c & c \\
c & c & c\end{array}$ & COAL \\
\hline & SHALE & 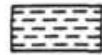 & $\begin{array}{c}\text { ORGANIC } \\
\text { SHALE }\end{array}$ \\
\hline
\end{tabular}

SYSTEMS TRACT (ST)

$$
\begin{aligned}
\text { HST } & \text { HIGHSTAND ST } \\
\text { SMW } & \text { SHELF MARGIN WEDGE } \\
\text { TST } & \text { TRANSGRESSIVE ST } \\
\text { LST } & \text { LOW STAND ST }
\end{aligned}
$$

Figure 9. Wireline log data from Sites 762 (right) and 763 (left) on the southern Exmouth Plateau for the gamma-ray (SGA and SGR) and resistivity (ILD to the right and ILM to the left; no crossover) logs. Also shown are the interpreted lithology, log units, relative sea level, and correlation between the two sites. 


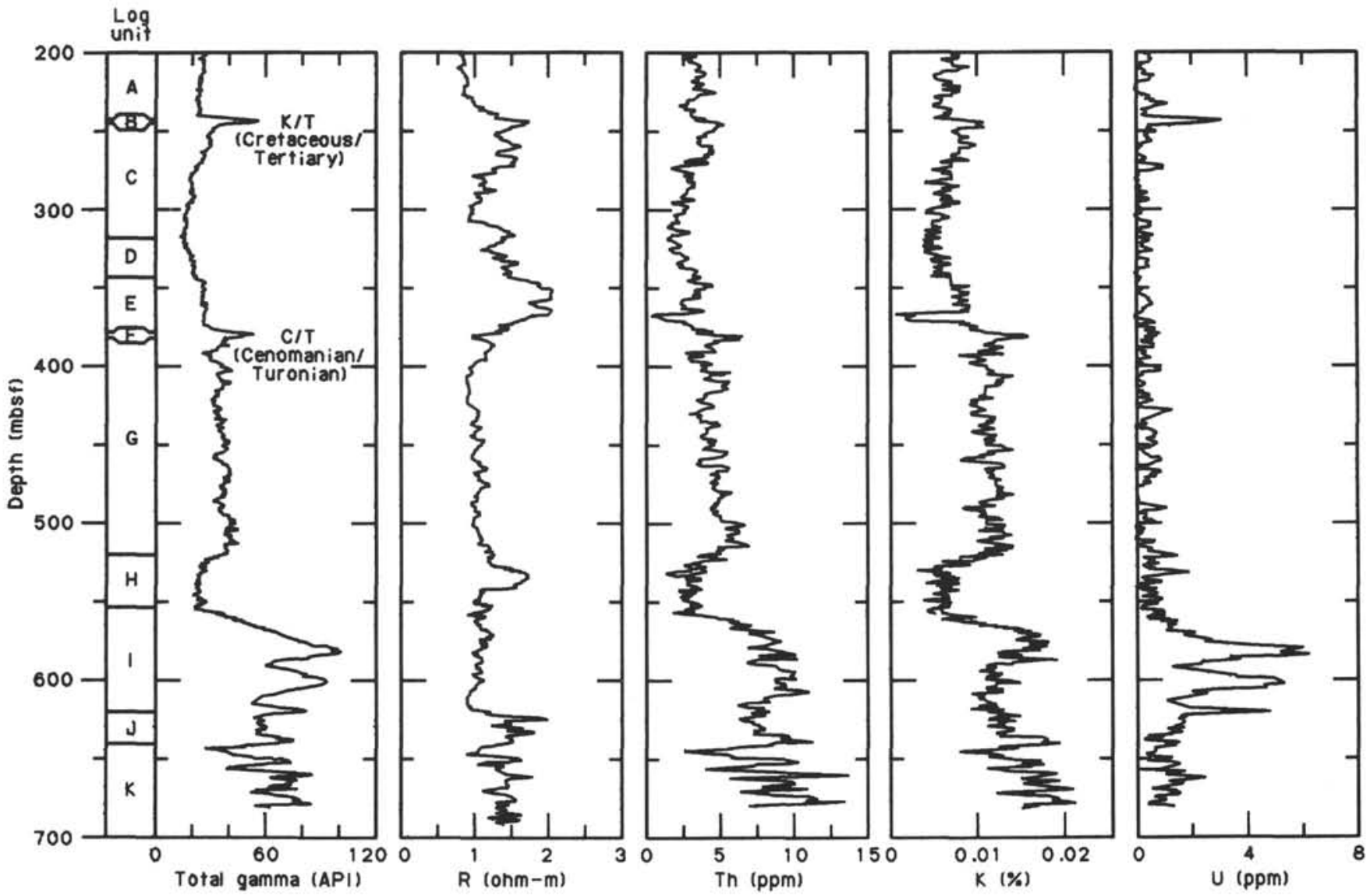

Figure 10. Total gamma-ray, resistivity (R), and spectral gamma-ray logs for the relative abundance of thorium (Th), potassium (K), and uranium (U) from Site 763. The clay-rich clastic strata of the Barrow Group and Muderong Shale can be identified from the high gamma-ray response below 578 mbsf. The middle Cretaceous to Tertiary chalks and oozes above 555 mbsf display a low gamma-ray response.

diminished gamma-ray response continues to the top of the logged interval at $1566 \mathrm{mbsl}$ (198.5 mbsf). Within this interval is a thin zone of higher resistivity at $1912.5-1896.5 \mathrm{mbsl}$ (545-529 mbsf), followed upward by a broad interval of little change to a prominent peak in the gamma-ray log at $1750 \mathrm{mbsl}(382.5 \mathrm{mbs})$ and then a return to low gamma-ray response. The identification of $\log$ trends and characteristic response patterns has enabled the definition of $13 \mathrm{log}$ units between 2045 and $1750 \mathrm{mbsl}(677.5$ and $382.5 \mathrm{mbsf})$.

\section{Log Character at Site 762}

At Site 762, the number of available logs is greater than at Site 763 , but the Lower Cretaceous section is thinner. The log interpretation at Site 762 concentrated again on gamma-ray and electric logs (Fig. 9) as these data enabled correlation with features and trends evident at Site 763 (Fig. 9) and the adjacent industry well, Eendracht-1. Sonic and density logs (Figs. 11 and 12) show clear trends and enabled comparison with seismic data; the photoelectric effect, porosity, and some elemental logs also display clear trends and correlations. Poor data quality below $2241 \mathrm{mbsl}$ ( $881 \mathrm{mbs}$ ) restricted interpretations beyond this depth. Clear resistivity peaks occur at 2220.9, 2215.9, 2204.4, and 2191.7 mbsl (860.9, 855.9, 844.4 , and $831.7 \mathrm{mbsf}$ ) (Fig. 9). These peaks all correlate with gamma-ray troughs and density, velocity, and porosity log peaks. Peaks in gamma-ray logs and in the uranium content of the gamma-ray log occur at 2193.4-2196.4, 2205.7-2210.7, and 2227.92234.9 mbsl ( $833.4-836.4,845.7-850.7$, and 867.9-874.9 mbsf). A sharp kick occurs in almost all logs at $2193.2 \mathrm{mbsl}$ ( $833.2 \mathrm{mbsf}$ ) and is characterized by a sharp reduction in the gamma-ray log (Fig. 9) and silicon yield and increases in velocity, resistivity (Fig. 11), and calcium yield. An isolated gamma-ray log peak and associated electric and sonic log troughs occur at $2170.5 \mathrm{mbsl}$ ( $810.5 \mathrm{mbsf})$. The combination of all of the events allows the logs to be subdivided into nine units (Fig. 9).

\section{Lithologic Interpretation}

Intervals of high ( $>3-4 \mathrm{ohm}-\mathrm{m})$ resistivity and low interval transit time indicate low porosity and permeability, and in the Lower Cretaceous sections at Sites 763 and 762 are interpreted (Fig. 9) to represent a compact limestone lithology at Sites 762 (e.g., 2220.9, 2215.9, 2204.4, and $2291.7 \mathrm{mbsl} ; 860.9$, 855.9, 844.4, and $931.7 \mathrm{mbsf}$ ) and 763 (1991-2002, 2014-2017, and 2226-2228 mbsl; 623.5-634.5, 646.5-649.5, and 658.5$660.5 \mathrm{mbsf}$ ). This interpretation is supported by high photoelectric effect values, low gamma-ray, high density, and low neutron porosity responses. Further confirmation is given by reference to recrystallized limestones in the cores, such as Section 122-762C-82X-2, 78-100 cm, and Cores 122-763B48X, 122-763B-49X, and 122-763B-54X.

Above $2192.9 \mathrm{mbsl}(832.9 \mathrm{mbsf})$ at Site 762 and $1923 \mathrm{mbsl}$ (555.5 mbsf) at Site 763 the radioactive content of the sediments as reflected in the gamma-ray log displays a marked decrease (Fig. 9) associated with an increase in density, photoelectric effect, resistivity, and calcium yield. These properties are consistent with a shift from clastic- to carbonate-dominated sedimentation. The sediments above 2192.9 mbsl ( $832.2 \mathrm{mbsf}$ ) at Site 762 and above $1923 \mathrm{mbsl}$ ( $555.5 \mathrm{mbsf}$ ) at Site 763 are therefore interpreted as mostly marls, chalks, and oozes whereas those below these depths are interpreted to 

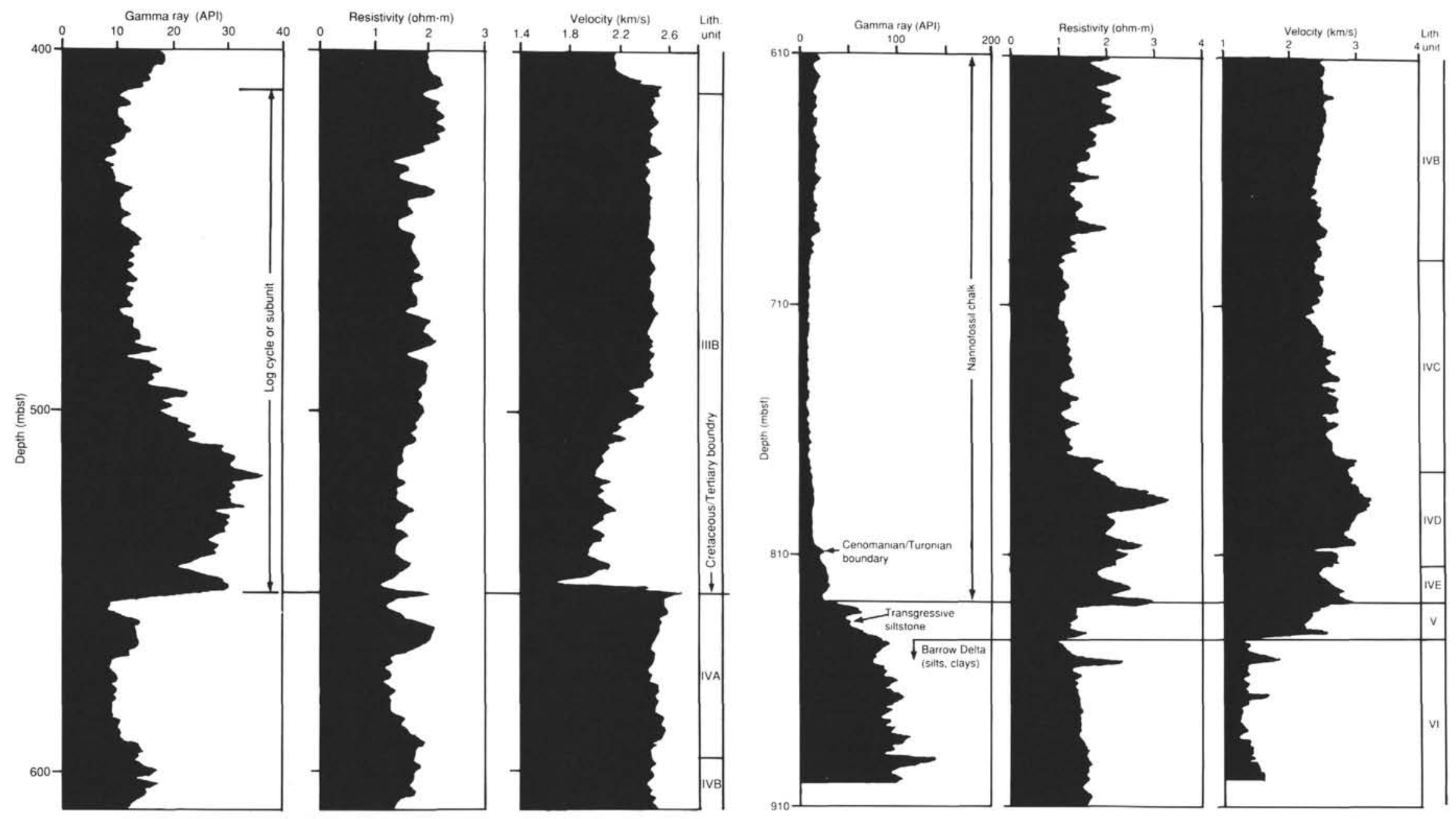

Figure 11. Total gamma-ray, resistivity, and velocity logs for the interval from 400 to $910 \mathrm{mbsf}$ (note scale change), Hole $762 \mathrm{C}$. Also shown is the correlation of the logs to lithologic units defined in Haq, von Rad, O’Connell, et al. (1990). 

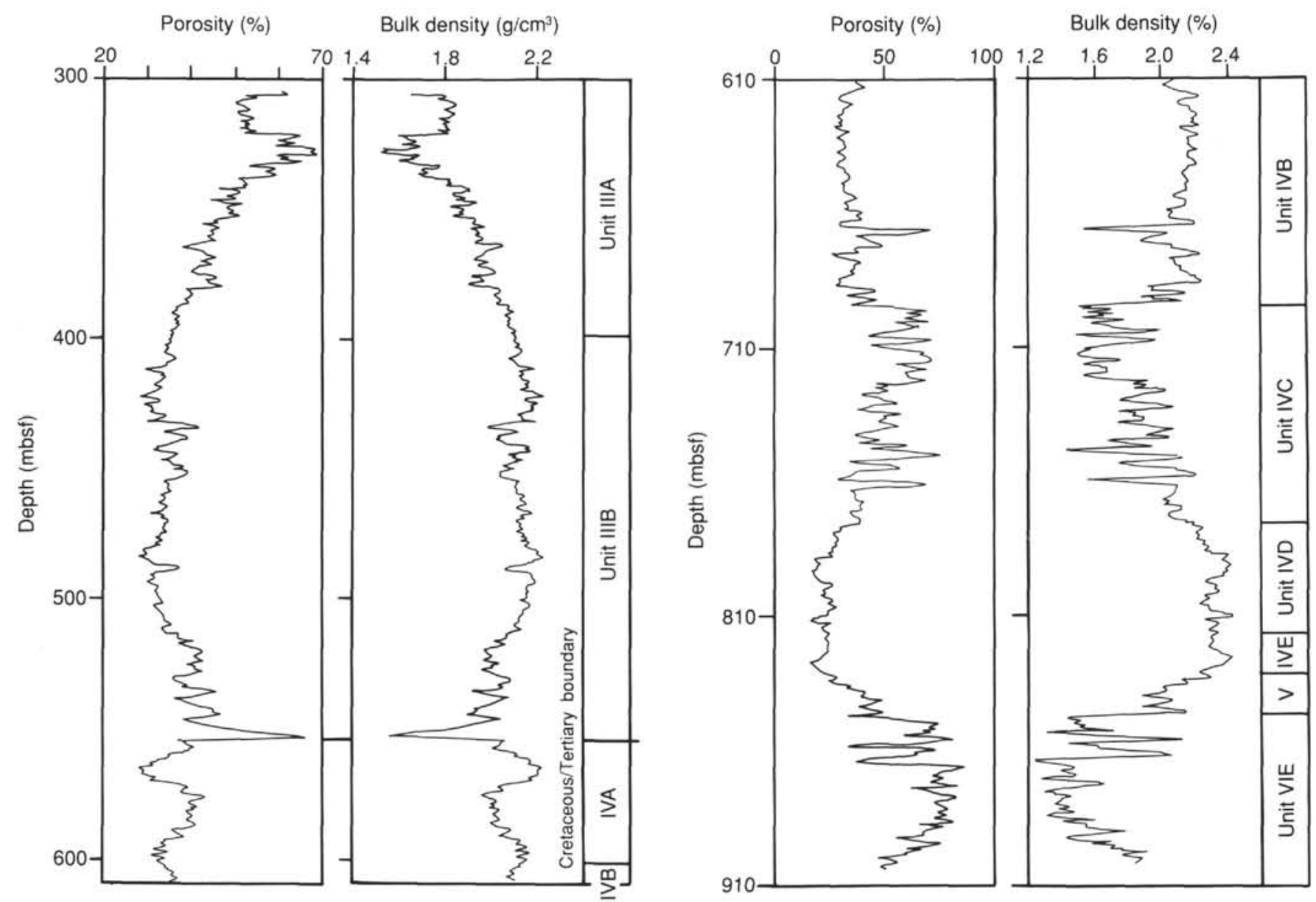

Figure 12. Porosity (calculated from density) and bulk density for the interval from 300 to 910 mbsf, Hole $762 \mathrm{C}$. Also shown is the correlation of the logs to lithologic units defined in Haq, von Rad, O'Connell, et al. (1990).

consist mostly of mud(stones) and sand(stones). The intervals 2011-2018 and 2023-2028 mbsl (643.5-650.5 and 655.5-660.5 mbsf) at Site 763 have a low gamma-ray response and a low resistivity; industry logs from the adjacent Vinck-1 well also show an increased interval transit time in these depth ranges. The lithology is interpreted to be unconsolidated sand. Core recovery in this interval was poor, but those sediments examined all contained a sand component.

The remainder of the sediments below the transition to marls, chalks, and oozes at both sites are interpreted to be mudstones. Several intervals in this lithology contained particularly high gamma-ray responses characterized by peaks in uranium content at Sites 762 (e.g., 2195, 2208, and $2230 \mathrm{mbsl}$; $835,848$, and $876 \mathrm{mbsf})$ and 763 (1946, 1966, and $1986 \mathrm{mbsl}$; $578.5,598.5$, and $618.5 \mathrm{mbsf}$ ). The intervals are interpreted as organic-rich mudstones deposited under reducing conditions. These intervals in the core contain glauconite, zeolite, and belemnite-rich mudstones, and the organic geochemistry indicated that most of the intervals that were sampled contain high levels of organic carbon.

\section{Correlation of Sites 762 and 763}

Reference to the clear gamma-ray peak associated with the Cenomanian/Turonian boundary and to the distinctive limestone units allows a confident correlation of the logs to core depths. At Hole $763 \mathrm{C}$ the shipboard logs are between 1.45 to $3.43 \mathrm{~m}$ higher than the core whereas at Hole 762B the shipboard seismic-stratigraphic logs are $2.9 \mathrm{~m}$ higher than the core, the geochemical logs are $4.9 \mathrm{~m}$ higher, and the lithodensity logs are $1.5 \mathrm{~m}$ higher. The lithologic and $\log$ units defined in the following can be used to correlate between Sites 762 and 763. These correlations again are based mainly on corresponding resistivity and gamma log peaks (Fig. 9). In particular, the black shale peaks in the gamma-ray log associated with Cenomanian/Turonian boundary can be correlated between sites, as can an unnamed lower Aptian-Albian limestone. The characteristic series of limestone peaks in the Barrow Group of Berriasian age can be seen at both sites, indicating that they are of regional extent. Several of the gamma-ray peaks and the long transitional unit between clastic and carbonate units observed at Site 763 are missing at Site 762 , indicating a hiatus from Late Hauterivian to Aptian may occur at this site at the sharp kick seen at 2192.9 mbsl (832.9 mbsf).

\section{Interpretation of Depositional Environments and Relative Sea Levels on the Exmouth Plateau}

The $\log$ units and their characteristics at Sites 762 and 763 suggest a broad pattern of terrigenous clastic deposition in a distal setting followed by a transition into a carbonate-dominated environment. This transition occurs sharply at 2192.9 mbsl ( $832.9 \mathrm{mbsf})$, between units 7 and 12 at Site 762 and over a broader zone (unit 10) at Site 763. From the base of the logged interval at Site 763 to $2011 \mathrm{mbsl}$ (643.5 mbsf) the interpreted lithology consists of interbedded muds, sands, and cemented sandstones and limestones. A similar lithology is 
interpreted below $2224.4 \mathrm{mbsl}(864.5 \mathrm{mbsf})$ at Site 762 . In conjunction with seismic stratigraphic analyses (see Boyd et al., this volume) this lithology is interpreted as deposited seaward of a low-relief, prograding continental margin/slope (cf. Erskine and Vail, 1988). Limestones and cemented sandstones in this sequence are interpreted as intervals of low clastic supply or progradation. For example, the limestones below 2030 mbsl (662.5 mbsf) at Site 763 and 2232 mbsl ( 872 mbsf) at Site 762 can be correlated to a seismic downlap surface indicating a hiatus or a period of low deposition to nondeposition in a transgressive to early highstand systems tract. The overlying period of deposition between 2011 and $2030 \mathrm{mbsl}$ ( 643.5 and $662.5 \mathrm{mbsf}$ ) at Site 763 and between 2224 and $2232 \mathrm{mbsl}$ ( 864 and 872 mbsf) at Site 762 contains mainly sandstones and mudstones and is interpreted as deposited in a prodelta setting with coarser clastic sediments supplied mainly by gravity processes. Seismic data indicate that during this interval the adjacent coastline made its closest approach to Sites 762 and 763 (less than $8 \mathrm{~km}$ at Site 763). This progradation occupied the late highstand systems tract and possibly also a short interval of lower relative sea level. Palynological and seismic data (see Brenner et al., this volume; Boyd et al., this volume) indicate that deposition was continuous from the underlying limestones of the early highstand systems tract.

The interval of rapid clastic deposition is followed at both sites by an interval of initially increasing gamma-ray response followed by an interval of lower gamma-ray response at Sites 762 (2221.92224 mbsl; 861.9-864.9 mbsf) and 763 (2005.5-2011 mbsl; 638$643.5 \mathrm{mbsf}$ ) and several resistivity peaks at $2214.3-2221.9 \mathrm{mbsl}$ (854.3-861.9 mbsf) at Site 762 and 1994.5-2005.5 mbsl (627-638 mbsf) at Site 763 . This sequence is interpreted as the abandonment of deltaic progradation accompanied by a transgression and subsequent slow deposition. The gamma-ray peak (unit 3) is interpreted as representing a maximum flooding surface. The shoreline and active clastic supply never returned to this location and all subsequent clastic deposition took place in a sediment-starved distal location. Palynological data (Brenner et al., this volume) indicate that deposition in this interval was slow but continuous during and after abandonment and that the limestones therefore occupy a highstand systems tract. Above the zone of resistivity peaks at both sites is a second gamma-ray peak containing high uranium and organic carbon contents (unit 5). The interval surrounding this gamma-ray peak at $1985.5-1994.5 \mathrm{mbsl}(618.0-627.0 \mathrm{mbs})$ at Site 763 and 2205.4-2214.3 mbsl (845.4-854.3) at Site 762 was observed in the cores to contain abundant glauconite and belemnites. It, like unit 3 , is interpreted as a reducing environment following a transgression and represents a maximum flooding surface. Sediment supply was limited here and a hiatus of one dinoflagellate zone is indicated at Site 763 (1990.5 mbsl; $623 \mathrm{mbsf})$. Immediately overlying the gamma-ray peak at Site 762 (2202.9-2205.4 mbsl; 849.5$845.4 \mathrm{mbsf}$ ) is a resistivity, photoelectric effect, velocity, and density peak interpreted as a limestone occupying a condensed section in the overlying highstand systems tract.

The interval between 2192.9 and 2202.9 mbsl $(832.9$ and $842.9 \mathrm{mbsf}$ ) at Site 762 and between 1963 and $1985.5 \mathrm{mbsl}$ ( 595.5 and 618 mbsf) at Site 763 (units 6 and 7 at both sites) consists of a trough followed by a peak in gamma-ray response but few other log features. The high uranium content present in the logs and high organic carbon content including marine algal matter in the cores suggest that the gamma-ray peak occurs in another reducing environment following transgression and that the complete gamma-ray cycle represents either a full cycle of relative sea level or a parasequence (Van Wagoner et al., 1987).

An extensive hiatus is indicated at $2192.9 \mathrm{mbsl}$ ( $832.9 \mathrm{mbsf})$ at Site 762 . At Site 763 another full gamma-ray log cycle between 1946 and $1963 \mathrm{mbsl}$ ( 578.5 and $595.5 \mathrm{mbsf}$ ) is also assumed from similar reasoning to result from a relative sea-level cycle and to occupy either a full sequence or a parasequence. The overlying transition from 1926 to 1946 mbsl (558.5 to 578.5 mbsf) (unit 10 ) represents a gradual reduction in gamma-ray response resulting from a progressive reduction of clay content and, hence, clastic input. The transition and contemporaneous hiatus at Site 762 occur at the position interpreted as following continental breakup and an M4 spreading-ridge jump based on magnetic anomalies in the adjacent Cuvier Abyssal Plain (Fullerton et al., 1989). The log responses represent the influence of gradual subsidence following breakup and the transition to a pelagic carbonate environment. The only exception occurs at 2170.65-2170.88 mbsl (810.65-810.88 mbsf) at Site 762 (Fig. 11) and $1750 \mathrm{mbsl}$ (382.5 mbsf) at Site 763 (Fig. 10). This gamma-ray peak is the black shale of the Cenomanian/Turonian boundary, which corresponds to a widespread erosion surface on the Exmouth Plateau (Boyd et al., this volume) and is also interpreted globally as an oxygen minimum event with an associated rise in the carbonate compensation depth (Arthur et al., 1987).

\section{DISCUSSION}

The Mesozoic sedimentary sequences interpreted from the wireline log data at Sites 759-764 represent two depositional wedge sequences (Boote and Kirk, 1989) of the northwest Australian margin (Fig. 2). The first of these is Triassic in age and was encountered only at sites on the Wombat Plateau. Leg 122 drilling encountered the upper Rhaetian-Carnian part of this cycle. Although encountered in a distal location relative to the Exmouth Plateau and the Rankin Trend, Carnian to Rhaetian sediments indicate a broad but fluctuating pattern of submergence, from more terrestrial to more marine facies. This is shown, for example, in the Carnian predominance of interpreted deltaic facies at the base of Site 759 followed by the overlying occurrence of more common limestone intervals through the Norian and the Rhaetian transition (e.g., at Site 761) to pure carbonate reef facies at Site 764. In these respects, the results from the log interpretations fit well with lithologic and seismic interpretations of increasing marine influence at the close of the depositional cycle in Late Triassic time, which is lithologically equivalent to the Brigadier Formation on the northwest shelf and also similar to the seismic transition observed in the Triassic sediments between Sites 762 and 763 on the southern Exmouth Plateau (see Boyd et al., this volume).

Within the Triassic wedge, Norian and Carnian sediments at Sites 759 and 760 were deposited predominantly within the highstand systems tract. The occurrence of a Norian placer deposit may be indicative of a fall in sea level. Rhaetian carbonates at Sites 761 and 764 may be interpreted as the product of a transgressive systems tract overlain by a highstand systems tract with a possible further sequence boundary at the top of the reefal complex at Site 764. Like comparable areas along the Barrow-Dampier rift most of the Jurassic was a time of block faulting, uplift, erosion, tilting, and nondeposition and can be correlated as a major log event across the Wombat Plateau.

The second depositional wedge cycle seen in the Leg 122 log data from northwest Australia is of Neocomian age and can be tectonically correlated to the final breakup event along this margin. The log signatures of the Barrow Group at Sites 762 and 763 record the progradation of a pre-breakup clastic wedge from an uplifted source along the eastern margin of the present Cape Range Fracture Zone. The interpreted transgressive systems tracts deposited after wedge abandonment (unit 3 ) and the succeeding limestones (unit 4) deposited in con- 
densed sections of late Berriasian-Valanginian age record the removal of this major clastic source during the late Valanginian (M10) breakup event (Fullerton et al., 1989). The overlying Hauterivian interval of cyclic organic claystone deposition records the westward passage of the Greater India continental block along the southern transform margin of the Exmouth Plateau. The final transition to a carbonate-dominated environment is recorded in the decreasing gamma log trend from $\log$ unit 9 through unit 10 at Site 763 and follows the loss of clastic sediment supply and the onset of subsidence as Greater India cleared the Australian continent following the M4 ridge jump at the end of the Hauterivian (Fullerton et al., 1989). In this context, the transition to carbonate-dominated environments on the southern Exmouth Plateau at the close of the Neocomian cycle is paralleled by the Early Cretaceous transgression on the Wombat Plateau. On the Wombat Plateau this transgression is recorded as a major log unconformity and is represented as a reworked shoreface sandstone at Site 761 which passes upward into marine sediments that represent the eventual transition to a permanently deep marine setting. Like the southern Exmouth Plateau, the transition here is also represented by a upward-diminishing gamma log trend reflecting gradual deepening during post-rift subsidence and the removal of the clastic supply source.

\section{CONCLUSIONS}

1. Detailed correlation of log units, lithologic interpretations, and depositional systems tracts was possible at the Exmouth Plateau sites. Results indicate clastic sedimentation of sandstones and mudstones, followed by abandonment indicated by limestones and organic mudstones, and then subsidence and transition to limestones, chalks, and oozes of a deep-water marine environment.

2. Correlation of the sites on the Wombat Plateau is difficult from log analysis alone. Log correlations can be tied at the top Triassic unconformity with additional possible correlations of Norian limestone and radioactive sandstone events between Sites 759 and 760 . Relative sea-level interpretations may enable broad facies correlations at Sites 761 and 764 .

3. Wireline log data from the Exmouth and Wombat plateaus document two tectonic depositional cycles on the northwest Australian margin. The first is Late Triassic in age and followed a Permian rifting event. It was encountered only on the Wombat Plateau. The second is Early Cretaceous, documents a continental breakup event, and can be identified on both the Wombat and Exmouth plateaus. Superimposed on the large tectonic events are cycles of shorter duration reflecting sea-level oscillations and fluctuations in sediment supply.

4. The post-breakup rift to drift transition is everywhere documented by an upward-decreasing gamma log trend reflecting the reduction and removal of clastic supply followed by a transition to carbonate deposition. This occurs both in the Norian-Rhaetian part of the Triassic cycle and the Neocomian-Aptian part of the Cretaceous cycle.

\section{ACKNOWLEDGMENTS}

We would like to acknowledge the assistance given in data collection while at sea on the JOIDES Resolution by the crew and the ODP technical and logistics personnel and in particular for the help given by D. Hsieu (Schlumberger), R. Wilkens, and X. Golovchenko (LDGO). We would also like to acknowledge the drafting assistance provided at British Petroleum (Glasgow), funding provided by a Canadian NSERC CSP grant to RB, an Alexander von Humboldt Fellowship provided to RB, and facilities provided by Geomar Institute, Kiel, FRG, while RB was on sabbatical leave.

\section{REFERENCES}

Arthur, M. A., Schlanger, S. O., and Jenkyns, H. C., 1987. The Cenomanian-Turonian oceanic anoxic event, II. Paleoceanographic controls on organic-matter production and preservation. In Brooks, J., and Fleet, A. J. (Eds.), Marine Petroleum Source Rocks. Geol. Soc. Spec. Publ. London, 26:401-420.

Audley-Charles, M. G., 1988. Evolution of the southern margin of Tethys (North Australian region) from early Permian to Late Cretaceous. In Audley-Charles, M. G., and Hallam, A. (Eds.), Gondwana and Tethys: Geol. Soc. Spec. Publ. London, 37:79100.

Barber, P. M., 1982. Paleotectonic evolution and hydrocarbon generation of the central Exmouth Plateau. APEA J., 22:131-134.

Boote, D.R.D., and Kirk, R. B., 1989. Depositional wedge cycles on an evolving plate margin, western and northwestern Australia. AAPG Bull., 73:216-243.

Erskine, R. D., and Vail, P. R., 1988. Seismic stratigraphy of the Exmouth Plateau. In Bally, A. W. (Ed.), Atlas of Seismic Stratigraphy. AAPG Stud. in Geol., 27:163-173.

Exon, N. F., von Rad, U., and von Stackelberg, U., 1982. The geological development of the passive margins of the Exmouth Plateau off northwest Australia. Mar. Geol., 47:131-152.

Exon, N. F., and Willcox, J. B., 1980. The Exmouth Plateau: stratigraphy, structure and petroleum potential. Bull. Bur. Miner. Resour. Geol. Geophys. Aust., 199.

Fullerton, L. G., Sager, W. W., and Handschumacher, D. W., 1989. Late Jurassic-Early Cretaceous evolution of the eastern Indian Ocean adjacent to northwest Australia. J. Geophys. Res., 94:2937-2953.

Haq, B. U., Hardenbol, J., and Vail, P. R., 1987. Chronology of fluctuating sea levels since the Triassic. Science, 235:1156-1167.

Haq, B. U., von Rad, U., O'Connell, S., et al., 1990. Proc. ODP, Init. Repts., 122: College Station, TX (Ocean Drilling Program).

Rider, M. H., 1986. The Geological Interpretation of Well Logs: London (Blackie/Halstead Press).

Vail, P. R., 1987. Seismic stratigraphy interpretation utilizing sequence stratigraphy. In Bally, A. W. (Ed.), Atlas of Seismic Stratigraphy. AAPG Stud. Geol., 27(2):1-10.

Van Wagoner, J. C., Mitchum, R. M., Jr., Posamentier, H. W., and Vail, P. R., 1987. Key definitions of sequence stratigraphy. In Bally, A. W. (Ed.), Atlas of Seismic Stratigraphy. AAPG Stud. Geol., 27(2):11-14.

von Rad, U., and Exon, N. F., 1983. Mesozoic-Cenozoic sedimentary and volcanic evolution of the starved passive continental margin off northwest Australia. In Watkins, J. S., and Drake, C. L. (Eds.), Studies in Continental Margin Geology: AAPG Mem., 34:253-281.

von Rad, U., Thurow, J., Haq, B. U., Gradstein, F., Ludden, J., and ODP Leg 122/123 Shipboard Scientific Parties, 1989. Triassic to Cenozoic evolution of the NW Australian continental margin and the birth of the Indian Ocean (preliminary results of ODP Legs 122 and 123). Geol. Rundsch., 78:1189-1210.

Williamson, P. E., and Falvey, D. A., 1988. Preliminary post-cruise report, Rig Seismic research cruises 7 and 8: deep seismic structure of the Exmouth Plateau. BMR Geol. Geophys. Rec., 1988/31.

Date of initial receipt: 30 May 1990

Date of acceptance: 9 May 1991

Ms 122B-119 